\title{
HUBUNGAN PENGAJARAN REMEDIAL DENGAN PRESTASI BELAJAR EKONOMI SISWA KELAS X DI SMA YAYASAN PERGURUAN GAJAHMADA MEDAN
}

\author{
${ }^{1}$ Dewi Sartika*, ${ }^{2}$ James Ronald Tambunan \\ ${ }^{1,2,3}$ Manajemen Informatika, Akademi Manajemen Informatika Komputer Widya Loka \\ Medan, Indonesia \\ *e-mail: jamesronaldtambunan@gmail.com
}

Received: September 20, 2021, Revised: October 15, 2021 Accepted: October 20, 2021

\begin{abstract}
Abstrak
Penelitian ini bertujuan untuk mengetahui hubungan antara pengajaran remedial dengan prestasi belajar siswa kelas X di SMA Yayasan Perguruan Gajahmada Medan. Teknik pengumpulan data terdiri dari observasi, wawancara, dan angket. Penelitian ini dilaksanakan di SMA Yayasan Perguruan Gajahmada Medan yang beralamatkan di jalan H.M Said No.19 Medan. Populasi dalam penelitian ini adalah seluruh siswa kelas X di SMA Yayasan Perguruan Gajahmada sebanyak 108 orang yang terbagi menjadi 2 kelas. Sampel yang digunakan dalam penelitian ini sebanyak 48 orang siswa dengan menggunakan teknik random sampling( sampel diambil secara acak) yang masing-masing kelas diambil $45 \%$ siswa dari populasi yang ada. Teknik Pengumpulan data penelitian untuk variabel X (pengajaran remedial) dan variabel Y (prestasi belajar siswa) yang dilakukan dengan menggunakan angket (kuisioner) yang telah teruji validitas dan reliabilitasnya dan dari hasil perhitungan angket variabel $\mathrm{X}$ dan variabel $\mathrm{Y}$ adalah valid dan reliabel. Kemudian diperoleh rata-rata nilai angket variabel X sebesar 3,25 dikategorikan sangat baik, dan nilai rata-rataprestasi belajar siswa diperoleh 77,92 dikategorikan baik. Teknik analisis data yang dipergunakan adalah Korelasi Product Moment dan uji hipotesis dengan menggunakan rumus Uji "t". Dari hasil Perhitungan Korelasi product moment diperoleh thitung sebesar 0,85 dan ttabel sebesar 0,285 yang berarti bahwa terdapat hubungan antara pengajaran remedial (x) dengan prestasi belajar siswa kelas X SMA Yayasan Perguruan Gajah Mada Medan T.P.2019/2020 pada taraf sangat kuat. Selanjutnya dalam pengujian hipotesis dengan menggunakan rumus Uji " $t$ " diperoleh thitung sebesar dan 10,965 ttabel sebesar 1,6801. Ini berarti thitung $>$ ttabel $(10,965>1,6801)$ pada taraf signifikansi $95 \%$ atau alpha $(\alpha) 0,05$ dengan $\mathrm{dk}=\mathrm{N}-2=48-2=46$. Dengan demikian hipotesis yang mengatakan bahwa : 'Terdapat hubungan yang positif dan signifikan antara Pengajaran remedial dengan prestasi belajar siswa kelas X SMA Yayasan Perguruan Gajahmada Medan T.P. 2019/2020 dapat diterima.
\end{abstract}

Kata kunci: pengajaran remedial, prestasi belajar siswa.

\begin{abstract}
This research aim to know the relation between instruction remedial with the achievement learn the student of tenth class SMA Yayasan Perguruan Gajah Mada Medan. Technique of data collecting consisted the observation, interview, and enquette. This research executed in SMA Yayasan Perguruan Gajah Mada Medan addressing in H.M Said No.19 Medan. Population in this research is entire student of tenth class SMA Yayasan Perguruan Gajah Medan as much 108 one who divisible become 2 class. Sampel used in this research as much 48 student people by using technique of random sampling ( sampel taken at random) what is each class taken by $45 \%$ student from existing population. Technique of Data collecting of research for the variable of $X$ (instruction remedial) and variable $Y$ (achievement learn the student) what is done by using enquette (kuisioner) which have been tested by the validity and the reliabel and from result of calculation of the enquette of variable of
\end{abstract}


$X$ and variable $Y$ is valid and reliabel. Then obtained by a mean assess the enquette of variable $X$ equal to 3,25 categorized is very good, and assess the average value from achievement learn of student obtained is 77,92 categorized is goodness. Technique analyse the data utilized by the Correlation of Product Moment test the hypothesis by using formula Test the " $t$ ". From result of Calculation of Correlation of product moment obtained by $t_{\text {hitung }}$ of equal to 0,85 and $t_{\text {tabel }}$ of equal to 0,285 meaning that there are relation between instruction remedial $(x)$ with the achievement learn by 2019/2020 academic year the student of tenth class of SMA Yayasan Perguruan Gajah Mada Medan at very strong level. Hereinafter in hypothesis examination by using formula Test the " $t$ " obtainedby] thitung [of] equal to and 10,965 ttabel [of] equal to 1,6801. This means $t$ hitung $>t$ tabel ( $10,965>1,6801$ ) at level significate $95 \%$ or alpha $(\alpha) 0,05$ by $d k=N-2=48-2=46$. Thereby hypothesis saying that : "There are relation which are positive and significate between Instruction remedial with the achievement learn the student of tenth class of SMA Yayasan Perguruan Gajah Mada Medan is acceptable.

Keywords: instruction remedial, the achievement learn the student

\section{Pendahuluan (Introduction)}

Pendidikan merupakan salah satu wahana yang dapat mewujudkan peningkatan sumber daya manusia sebagai tenaga terdidik dan terampil. Pendidikan juga merupakan suatu cara membenahi dan meningkatkan kemampuan berpikir seseorang. Namun pendidikan tidak hanya dimaksud untuk mengembangkan pribadi semata melainkan juga wawasan siswa.

Dalam rangka meningkatkan mutu pendidikan di Indonesia, telah banyak usaha yang dilakukan pemerintah, beberapa diantaranya adalah melakukan perubahan kurikulum yakni Cara Belajar Siswa Aktif (CBSA), Kurikulum Berbasis Kompetensi (KBK) dan Kurikulum Tingkat Satuan Pendidikan (KTSP) serta peningkatan mutu pengajar dan guru. Namun demikian usaha yang telah dilakukan oleh pemerintah tersebut belum mencapai hasil yang memuaskan, indikasinya dapat dilihat dari rata-rata hasil belajar siswa dari mata pelajaran yang diuji secara Nasional (UAN) untuk nilai IPA adalah 6,46 dan IPS termasuk Ekonomi Akuntansi 6,26 Tahun Pembelajaran 2008/2009 (Depdiknas 2008).

Berdasarkan uraian latar belakang masalah di atas, maka yang menjadi indentifikasi masalah yang timbul dalam penelitian ini adalah :

1. Mengapa harus dilakukan Pengajaran Remedial?

2. Langkah-langkah apa yang harus dilakukan guru untuk meningkatkan daya tangkap siswa terhadap pelajaran?

3. Apakah ada Hubungan kegiatan Pengajaran Remedial yang dilakukan terhadap peningkatan prestasi belajar ekonomi siswa?

4. Faktor-faktor apa saja yang mempengaruhi prestasi belajar di sekolah?

Berdasarkan identifikasi masalah di atas, tentang keterkaitan antara Pengajaran Remedial terhadap prestasi belajar siswa di sekolah, peneliti merasa perlu mengadakan pembatasan masalah dalam penelitian ini yaitu : Bagaimanakah Pengajaran Remedial dan hubungannya dengan pencapaian prestasi belajar ekonomi siswa kelas X Di SMA Yayasan Perguruan Gajah Mada Medan Tahun Pembelajaran 2019/2020?

Berdasarkan pembatasan masalah di atas, maka penulis merumuskan masalah pada : "Apakah ada Hubungan Pengajaran Remedial dengan Prestasi Belajar Ekonomi Siswa kelas X Di SMA Yayasan Perguruan Gajah Mada Medan Tahun Pembelajaran 2019/2020?

Penelitan ini dilakukan dengan tujuan :

1. Untuk mengetahui Pengajaran Remedial di SMA Yayasan Perguruan Gajah Mada Medan

2. Untuk mengetahui prestasi belajar ekonomi siswa di SMA Yayasan Perguruan Gajah Mada Medan. 
3. Untuk mengetahui Hubungan Pengajaran Remedial Dengan Prestasi Belajar ekonomi siswa di SMA Yayasan Perguruan Gajah Mada Medan.

Hasil penelitian diharapkan dapat :

1. Menambah wawasan penulis tentang Hubungan Pengajaran Remedial terhadap prestasi belajar ekonomi siswa

2. Sebagai bahan masukan dan pertimbangan bagi kepala sekolah dan guru di SMA Yayasan Perguruan Gajah Mada Medan dalam melaksanakan Pengajaran Remedial.

3. Sebagai bahan masukan bagi peneliti berikutnya dalam meneliti objek/masalah yang sama.

\section{Tinjauan Literatur (Literature Review)}

Sejak diterapkannya Kurikulum Berbasis Kompetensi dan sampai pada kurikulum sekarang yaitu Kurikulum Tingkat Satuan Pendidikan, siswa berhak mendapatkan remedial. Menurut Rleni (2007, online) menyatakan bahwa remedial adalah semacam perbaikan nilai. Jadi jika si anak belum mencapai nilai Kriteria Ketuntasan Minimal (KKM) alias jika nilainya masih merah maka siswa berhak mengikuti pengajaran perbaikan . remedial ini sama dengan nilai KKM.

Menurut Rusmini (2005:8) bahwa "Pengajaran Remedial merupakan suatu bentuk pengajaran yang bersifat mengobati, menyembuhkan atau membetulkan pengajaran dan membuatnya menjadi lebih baik dalam rangka mencapai tujuan yang maksimal."

Selanjutnya Makmun Menyatakan :

Pengajaran Remedial didefinisikan sebagai upaya guru untuk menciptakan suatu situasi yang memungkinkan individu atau kelompok siswa lebih mampu mengembangkan dirinya seoptimal mungkin sehingga dapat meningkatkan motivasi belajar siswa dan memenuhi kriteria keberhasilan minimal yang diharapkan.

Dari beberapa pendapat para ahli di atas bahwa Pengajaran Remedial merupakan pendekatan yang dilakukan guru untuk membantu siswa yang mengalami hambatan-hambatan dalam belajar sehingga mampu mengatasi kesulitan siswa dalam belajar sehingga tercapai tujuan pelajaran tersebut. Untuk mengetahui apakah seorang siswa mengalami kesulitan belajar atau tidak dengan cara melihat indikasi-indikasi menurut Hakim (2004:22) adalah :

1. Nilai mata pelajaran sering di bawah sedang. Indikasi ini merupakan indikasi yang paling mudah dilihat dan paling umum dipakai oleh siswa atau mahasiswa, pengajar dan orang tua.

2. Nilai yang diperoleh sering di bawah nilai rata-rata kelas. Indikasi ini juga dapat menunjukkan bahwa siswa mengalami kesulitan belajar.

3. Prestasi yang dicapai tidak seimbang dengan tingkat inteligensi yang dimiliki. Misalnya seorang siswa yang prestasi belajarnya sedang-sedang saja, tetapi mempunyai tingkat inteligensi diatas rata-rata, siswa seperti ini dapat dikatakan mengalami kesulitan belajar.

4. Perasaan siswa yang bersangkutan. Misalnya seorang siswa yagn mengalami kesulitan belajar.

5. Kondisi kepribadian siswa yang bersangkutan. Serorang siswa dapat dikatakan mengalami kesulitan belajar jika dalam proses mengajar siswa tersebut menunjukkan gejala tidak tenang, tidak betah diam, tidak konsentrasi, tidak semangat, apatis dan lain-lain.

Dari pendapat di atas, diketahui bahwa nilai mata pelajaran di SMA Yayasan Perguruan Gajah Mada Medan masih di bawah nilai Ketuntasan Minimal (KKM) untuk setiap siswanya, sedangkan untuk nilai rata-rata kelas juga masih di bawah nilai rata-rata. Di sekolah tersebut juga sering ditemukan prestasi yang tidak seimbang dengan tingkat intelegensi siswa. Sehingga dapat disimpulkan indikasi-indikasi yang dinyatakan oleh pakar diatas benar kalau siswa secara keseluruhan mengalami tingkat kesulitan dalam belajar.

Tugas utama guru sebagai pendidik sebagaimana ditetapkan oleh UU RI Nomor 20 Tahun 2003 tentang Sistem Pendidikan Nasional adalah "mengajar". Menurut Syah (2003:20) mengajar adalah "Kegiatan menyampaikan materi pelajaran, melatih keterampilan dan menanamkan nilai moral yang terkandung dalam materi pelajaran tersebut kepada siswa." 
Oleh karena itu, sebagai calon guru atau guru yang sedang bertugas sangat diharapkan mengerti benar seluk beluk mengajar baik dalam arti individual maupun dalam arti klasik. Dalam hal ini seorang guru dapat pula memahami metode-metode mangajar dan strategi mengajar, agar kegiatan proses mengajar diterima oleh siswa.

Sasaran akhir dari Pengajaran Remedial identik dengan pengajaran sebagaimana biasanya (pada umumnya), yaitu membantu siswa dalam batas-batas normalitas tertentu agar dapat mengembangkan diri seoptimal mungkin sehingga dapat mencapai tingkat penguasaan atau ketuntasan tertentu, sekurang-kurangnya sesuai dengan batas-batas kriteria keberhasilan yang dapat diterima. Mengingat sasaran strategi itu tidak selamanya dapat tercapai dengan pendekata system pengajaran maka perlu dicarai upaya pendekatan strategi itu.

Menurut Makmun (2004:357) ada 2 strategi dan teknik pendekatan Pengajaran Remedial yaitu : 1) Strategi dan Teknik Pendekatan yang bersifat kuratif dan 2) Strategi dan teknik yang bersifat preventif.

Dikatakan Pengajaran Remedial yang bersifat kuratif kalau dilakukan setelah program proses belajar mengajar utama selesai diselenggarakan.

Sasaran pokok dari strategi ini adalah :

a. siswa yang prestasinya jauh di bawah kriteria keberhasilan diusahakan pada suatu saat tertentu dapat memadai kriteria keberhasilan minimal tersebut.

b. Siswa yang sedikit masih kurang atau bahkan telah tinggi sekalipun prestasinya dari ukuran kriteria keberhasilan minimal, pada suatu saat dapat lebih disempurnakan.

Untuk mencapai sasaran pokok tersebut ada kemungkinan beberapa teknik antara lain :

1. Pengulangan, cara melaksanakannya diadakan pada jam tertentu yang telah ditetapkan sebelumnya, diadakan di luar jam pengajaran biasa, diadakan Pengajaran Remedial bagi siswa yang memiliki kesulitan belajar, dan diadakan pengulangan secara total.

2. Pengayaan, cara melaksanakannya dengan memberikan tugas rumah dan memberikan soal yang dikerjakan di kelas untuk diulang dikerjakan di sekolah.

Pendekatan yang kedua ditujukan kepada siswa tertentu yang berdasarkan informasi dapat diprediksi akan mengalami kesulitan dalam menyelesaikan suatu program studi tertentu yang akan ditempuhnya. Berdasarkan hasil pengamatan pada garis besarnya siswa yang dapat diidentifikasikan ke dalam 3 kategori yaitu :

1. Mereka yang diperkirakan akan mampu menyelesaikan program proses pengajaran utama sesuai dengan waktu yang telah disediakan.

2. Mereka yang diperkirakan akan sanggup menyelesaikan program lebih cepat dari waktu yang ditetapkan.

3. Mereka yang diperkirakan akan terlambat atau tidak akan dapat menyelesaikan program sesuai dengan batas waktu yang telah ditetapkan.

Semua strategi dan teknik Pengajaran Remedial di atas tujuannya adalah agar siswa dapat mengatasi hambatan-hambatan atau kesulitan-kesulitan yang dialami selama belajar.

Proses belajar adalah suatu aktivitas yang berlangsung dengan melibatkan bermacam-macam komponen yang saling berinteraksi dalam mencapai tujuan. Prestasi merupakan hasil yang dicapai seseorang ketika mengerjakan tugas atau kegiatan tertentu. Prestasi belajar yang dicapai oleh seseorang merupakan hasil interaksi beberapa faktor yang mempengaruhi baik dari dalam diri maupun dari luar diri individu.

Prestasi belajar terdiri dari dua kata yakni prestasi dan belajar "prestasi" adalah hasil yang telah dicapai dari dilakukannya atau dikerjakan sedangkan "belajar" adalah proses untuk memperoleh kepandaian atau ilmu ke arah adanya perubahan tingkah laku atau tanggapan yang disebabkan oleh pengalaman. Menurut Syah (2003:109) mengatakan bahwa prestasi belajar adalah merupakan peningkatan hasil melalui perubahan belajar yang dicapai oleh seseorang. Sedangkan Yasa (2007, online) mengatakan prestasi belajar dapat diartikan sebagai hasil yang dicapai oleh individu setelah mengalami suatu proses belajar dalam jangka waktu tertentu. Dan menurut Arikunto (2005:276) 
mengatakan prestasi mencerminkan tingkatan-tingkatan siswa, sejauh mana telah dapat mencapai tujuan yang ditetapkan di setiap bidang studi, symbol yang digunakan untuk menyatakan nilai, baik huruf maupun angka.

Untuk mencapai keberhasilan seseorang dalam prestasi belajar maka dipengaruhi oleh beberapa faktor. Slameto (2003:54) "bahwa prestasi belajar dipengaruhi oleh beberapa faktor". Secara garis besarnya dapt dibagi atas dua golongan yaitu faktor internal dan faktor eksternal.

Faktor internal ini mencakup kepada 1) intelegensi dimana siswa yang memiliki intelegensi tinggi lebih berhasil daripada siswa yang memiliki intelegensi yang rendah, 2) Minat, dimana kecendrungan yang tetap untuk memperhatikan dan mengenang beberapa kegiatan-kegiatan yang diminati seseorang diperhatikan terus menerus, 3) Bakat, jika pelajaran diberikan sesuai dengan bakatnya mak hasil belajarnya akan baik, 4) Perhatian, untuk dapat menjamin hasil belajar yang baik maka seseorang harus mempunyai perhatian terhadap bahan yang dipelajari, 5) Kesiapan, ini perlu diperhatikan dalam proses belajar karena bila seseorang belajar padanya sudah ada kesiapan, maka hasil belajarnya akan lebih baik, 6) Motif, di dalam menentukan tujuan dapat disadari atau tidak akan mencapai tujuan itu perlu dibuat, sedangkan yang menjadi penyebab berbuat adalah motif itu sendiri sebagai daya penggerak atau pendorong dan 6) Kematangan, suatu daya tingkat pertumbuhan seseorang dimana alat-alat tubuhnya siap untuk melaksanakan kecakapan baru.

Sedangkan untuk faktor eksternal terdiri atas 3 bagian yaitu 1) faktor keluarga, bahwa keluarga adalah lembaga pendidikan yang utama, 2) Faktor sekolah, yang mencakup kepada metode mengajar, kurikulum, disiplin, relasi guru dengan siswa, relasi siswa dengan siswa, pelajaran, keadaan gedung, dll, 3) Faktor masyarakat, merupakan faktor yang ada di masyarakat seperti budaya, nilainilai masyarakat yang juga berpengaruh terhadap belajar siswa. Pengaruh itu sendiri terjadi karena dalam lingkungan masyarakat yaitu kegiatan siswa, teman bergaul dan kehidupan masyarakat.

Pendidikan merupakan salah satu wahana yang dapat mewujudkan peningkatan sumber daya manusia sebagai tenaga terdidik dan terampil. Pendidikan juga merupakan suatu cara membenahi dan meningkatkan kemampuan berpikir seseorang. Namun pendidikan tidak hanya dimaksud untuk mengembangkan pribadi semata melainkan juga akar pengembangan bangsa.

Untuk meningkatkan mutu pendidikan, maka peranan guru dalam pengajaran harus ditingkatkan dengan melihat tingkat kesulitan belajar siswa. Pelaksanaan Pengajaran Remedial adalah salah satu strategi yang dapat digunakan oleh guru untuk mencapai ketuntasan belajar setiap individu yang dilakukan dengan mengidentifikasikan siswa yang mengalami kesulitan belajar, yang memerlukan bantuan akibat adanya kesulitan, kekurangan, kelemahan atau kegagalan dalam pembelajaran. Dengan dilaksanakannya Pengajaran Remedial, kepada siswa yang mengalami hambatan-hambatan maupun kesulitan belajar diharapkan dapat mengatasinya sehingga dapat tercapai pengajaran yang ingin dicapai.

Hipotesis merupakan rumusan kesimpulan yang bersifat sementara, yang harus diuji kebenarannya. Berdasarkan kerangka teoritis dan kerangka berpikir di atas, maka hipotesis dalam penelitian ini adalah : "Ada Hubungan yang positif dan signifikan antara Pengajaran Remedial Dengan Prestasi Belajar siswa di SMA Yayasan Perguruan Gajah Mada Medan ."

\section{$3 \quad$ Metode Penelitian (Research Method)}

Lokasi sebagai tempat atau objek yang dibutuhkan. Sesuai dengan judul, penelitian ini dilakukan pada tahun 2019/2020 maka peneliti mengambil lokasi penelitian di SMA Yayasan Perguruan Gajah Mada Medan yang beralamat di Jl. HM Said No.19 Medan.

Populasi adalah keseluruhan objek penelitian yang dapat terdiri dari manusia, hewan, benda dan tumbuhan atau yang lainnya yang memiliki karakteristik yang dapat memberikan data atau informasi yang dapat dibutuhkan. 
Dari pengertian diatas, yang menjadi populasi dalam penelitian ini adalah siswa kelas X SMA Yayasan Perguruan Gajah Mada Medan sebanyak 108 orang yang terbagi dalam 2 (dua) kelas.

Tabel 3.2.1

Jumlah Populasi Siswa kelas X

SMA Yayasan Perguruan Gajah Mada Medan

\begin{tabular}{|c|c|c|}
\hline No & Kelas & Jumlah siswa \\
\hline 01 & $\mathrm{X}-1$ & 56 \\
\hline 02 & $\mathrm{X}-2$ & 52 \\
\hline \multicolumn{2}{|c|}{ JUMLAH } & 108 \\
\hline
\end{tabular}

Sampel merupakan bagian dari populasi yang dapat mewakili seluruh populasi untuk dapat dijadikan sumber data atau sumber informasi dalam penelitian ini. Dalam menentukan besarnya sampel penulis berpedoman kepada pendapat Arikunto (2002:112) yang menyatakan bahwa :

Untuk sekedar ancer-ancer maka apabila sumber di bawah dari 100 orang, lebih baik diambil semua sehingga penelitiannya merupakan penelitian populasi. Selanjutnya jika jumlah subjeknya besar dapat diambil $10-15 \%$ atau $20-25 \%$ atau lebih.

Karena jumlah populasi penelitian ini lebih dari 100 maka penulis mengambil sampel secara acak (random sampling) sebanyak $45 \%$ dari populasi yang ada yaitu:

Tabel 3.2.2

\subsubsection{SMA Yayasan Perguruan Gajah Mada Medan}

Sampel Populasi Siswa Kelas X

\begin{tabular}{|c|c|c|c|}
\hline No & Kelas & Jumlah Siswa & Sampel 45\% \\
\hline 01 & $\mathrm{X}-1$ & 56 & 25 \\
\hline 02 & $\mathrm{X}-2$ & 52 & 23 \\
\hline \multicolumn{2}{|c|}{ Jumlah } & 108 orang & 48 orang \\
\hline
\end{tabular}

Dalam penelitian ini digunakan 2 (dua) variabel yaitu:

a. Variabel Bebas (X) adalah Pengajaran Remedial

b. Variabel Terikat (Y) adalah Prestasi Belajar

Adapun defenisi operasional dari variabel tersebut adalah:

a. Pengajaran Remedial adalah usaha yang dilakukan guru untuk perbaikan nilai siswa yang mengalami kesulitan belajar.

b. Prestasi Belajar Siswa adalah tingkat kemampuan maksimal yang dicapai oleh siswa yang biasanya prestasi belajar dinyatakan dalam bentuk nilai atau angka tertentu yang terdapat dalam buku raport siswa.

Untuk memperoleh data yang terdiri dari 4 (empat) pilihan yang masing-masing menggunakan teknik sebagai berikut:

1. Observasi

Peneliti menggunakan pengamatan (lembar observasi) dengan terjun kelapangan untuk memperoleh data dan melihat secara langsung situasi dan keadaan yang sebenarnya. Dalam hal ini peneliti melakukan pengamatan secara langsung bagaimana Pengajaran Remedial dan prestasi belajar siswa di SMA Yayasan Perguruan Gajah Mada Medan.

2. Wawancara

Dalam teknik ini, peneliti langsung mengadakan wawancara dengan responden dengan daftar responden dengan daftar pertanyaan yang sudah dipersiapkan terlebih dahulu yang terdiri dari dari beberapa pertanyaan seputar Pengajaran Remedial dan prestasi belajar ekonomi siswa.

3. Studi Dokumentasi 
Teknik ini digunakan untuk mengambil gambar/foto seputar kegiatan belajar mengajar ekonomi siswa. Serta digunakan untuk memperoleh data tentang prestasi prestasi belajar siswa yang dapat kita peroleh dari kumpulan daftar nilai (DKN) siswa kelas X SMA Yayasan Perguruan Gajah Mada Medan pada pelajaran ekonomi tahun 2019/2020.

4. Angket

Angket digunakan untuk melihat sejauh mana tingkat pengetahuan siswa terhadap Pengajaran Remedial dilakukan. Apakah siswa pernah melakukan Pengajaran Remedial atau tidak. Angket merupakan salah satu alat untuk mengumpulkan data dengan membuat daftar pernyataan secara tertulis dan melengkapi jawaban yang kelak diberikan kepada responden ( siswa) secara bebas memilih salah satu jawaban yang tersedia sebagaimana dengan keadaan yang ada disekolahnya. Dengan demikian angket ini diukur dan dinilai berdasarkan sejumlah pernyataan dengan beberapa alternatif jawaban dari setiap butir pernyataan Pengajaran Remedial sebanyak: 20 yang masingmasing diberi alternatif 4 pilihan dengan bobot nilai sebagai berikut:
a. Sangat Setuju $: 4$
b. Setuju : 3
c. Tidak Setuju : 2
d. Sangat Tidak Setuju $: 1$

Tabel 3.3

\subsubsection{Lay out angket Pengajaran Remedial}

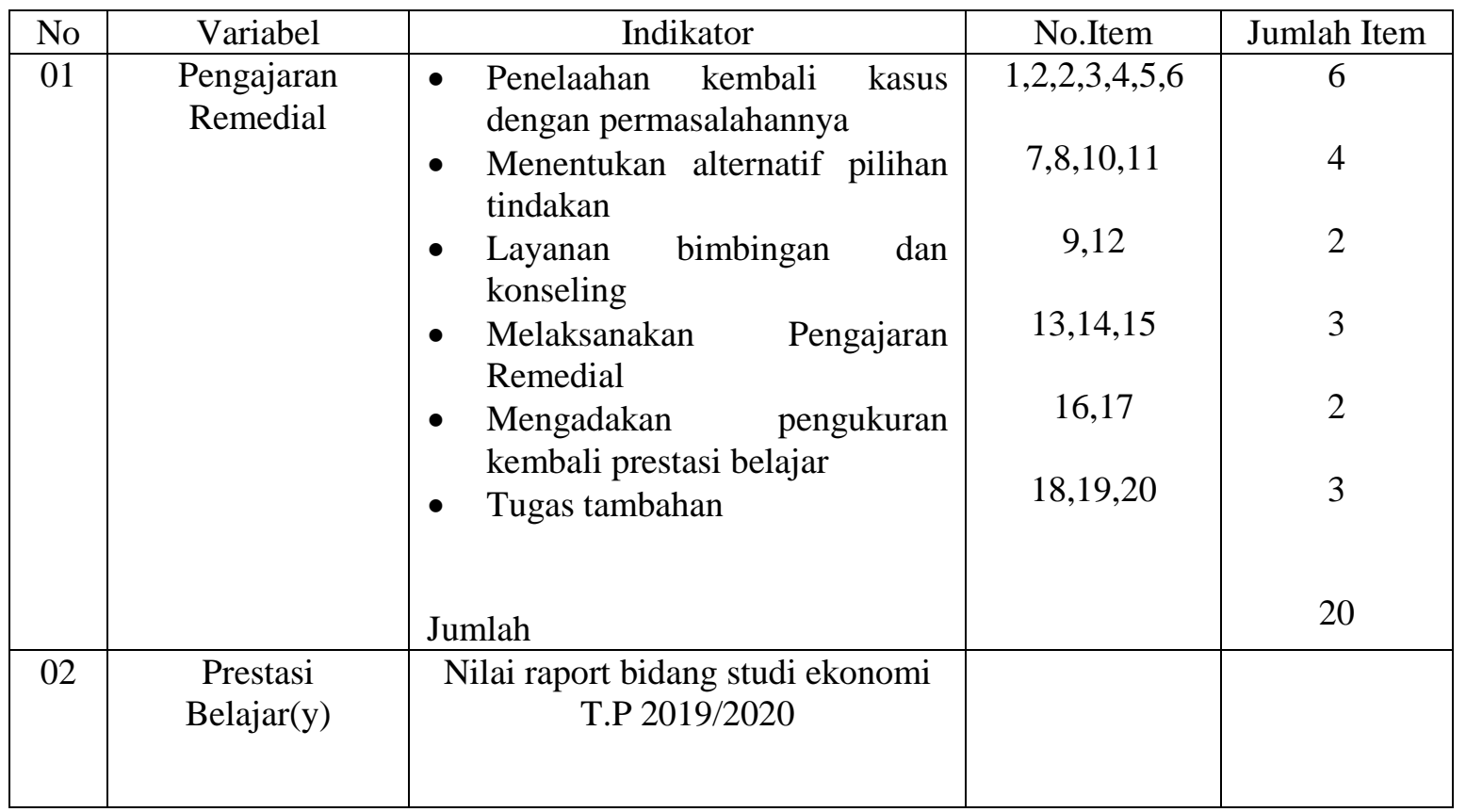

\section{Hasil dan Pembahasan (Results and Analysis)}

Sebelum dilakukan penelitian terlebih dahulu dilakukan uji coba instrument penelitian yang bertujuan untuk mengetahui validitas dan reliabilitas instrument yang dirancang sebanyak 20 soal dengan jumlah sampel sebanyak 48 siswa. Melalui metode tersebut, maka dapat diketahui bahwa angket yang disusun layak atau tidak untuk digunakan untuk menjaring data hasil penelitian. Dan dari hasil ujicoba instrument Pengajaran Remedial untuk semua item dinyatakan valid dan reliabel (lihat lampiran 3). 
Untuk mengetahui distibusi frekuensi tabulasi jawaban terhadap angket Pengajaran Remedial dapat ditunjukkan pada tabel dibawah ini:

Tabel 4.3

Distribusi Frekwensi Jawaban Atas Variabel Pengajaran Remedial (X) Berdasarkan Nomor Item Soal

\begin{tabular}{|c|c|c|c|c|c|c|c|c|c|c|c|}
\hline \multirow{3}{*}{$\begin{array}{c}\text { No } \\
\text { Item }\end{array}$} & \multicolumn{8}{|c|}{ Pilihan Jawaban } & \multirow{2}{*}{\multicolumn{2}{|c|}{ Jumlah }} & \multirow{2}{*}{$\begin{array}{c}\text { Rata- } \\
\text { rata }\end{array}$} \\
\hline & \multicolumn{2}{|c|}{$A=4$} & \multicolumn{2}{|c|}{$\mathbf{B}=\mathbf{3}$} & \multicolumn{2}{|c|}{$\mathrm{C}=2$} & \multicolumn{2}{|c|}{$D=1$} & & & \\
\hline & $\mathbf{F}$ & Sc & $\mathbf{F}$ & Sc & $\mathbf{F}$ & Sc & $\mathbf{F}$ & Sc & $\mathbf{F}$ & Sc & \\
\hline 1 & 33 & 132 & 7 & 21 & 3 & 6 & 5 & 5 & 48 & 164 & 3,42 \\
\hline 2 & 34 & 136 & 4 & 12 & 3 & 6 & 7 & 7 & 48 & 161 & 3,35 \\
\hline 3 & 32 & 128 & 5 & 15 & 6 & 12 & 5 & 5 & 48 & 160 & 3,33 \\
\hline 4 & 35 & 140 & 5 & 15 & 3 & 6 & 5 & 5 & 48 & 166 & 3,46 \\
\hline 5 & 35 & 140 & 4 & 12 & 3 & 6 & 6 & 6 & 48 & 164 & 3,42 \\
\hline 6 & 32 & 128 & 6 & 18 & 4 & 8 & 6 & 6 & 48 & 160 & 3,33 \\
\hline 7 & 24 & 96 & 7 & 21 & 5 & 10 & 12 & 12 & 48 & 139 & 2,89 \\
\hline 8 & 34 & 136 & 5 & 15 & 4 & 8 & 5 & 5 & 48 & 164 & 3,42 \\
\hline 9 & 27 & 108 & 6 & 18 & 5 & 10 & 10 & 10 & 48 & 146 & 3,04 \\
\hline 10 & 33 & 132 & 4 & 12 & 5 & 10 & 6 & 6 & 48 & 160 & 3,33 \\
\hline 11 & 33 & 132 & 6 & 18 & 3 & 6 & 6 & 6 & 48 & 162 & 3,37 \\
\hline 12 & 26 & 104 & 5 & 15 & 6 & 12 & 11 & 11 & 48 & 142 & 2,95 \\
\hline 13 & 32 & 128 & 4 & 12 & 5 & 10 & 7 & 7 & 48 & 157 & 3,27 \\
\hline 14 & 24 & 96 & 5 & 15 & 7 & 14 & 12 & 12 & 48 & 137 & 2,85 \\
\hline 15 & 34 & 136 & 4 & 12 & 4 & 8 & 6 & 6 & 48 & 162 & 3,37 \\
\hline 16 & 33 & 132 & 5 & 15 & 3 & 6 & 7 & 7 & 48 & 160 & 3,33 \\
\hline 17 & 23 & 92 & 5 & 15 & 9 & 18 & 11 & 11 & 48 & 136 & 2,83 \\
\hline 18 & 32 & 128 & 6 & 18 & 4 & 8 & 6 & 6 & 48 & 160 & 3,33 \\
\hline 19 & 34 & 136 & 4 & 12 & 5 & 10 & 5 & 5 & 48 & 163 & 3,39 \\
\hline 20 & 31 & 124 & 5 & 15 & 6 & 12 & 6 & 6 & 48 & 157 & 3,27 \\
\hline & & & & JUN & & & & & & & 64,95 \\
\hline & & & $\mathrm{T}$ & AT & ES & $\overline{\text { URI }}$ & $\overline{A N}$ & & & & 3,25 \\
\hline
\end{tabular}

Dengan membandingkan harga rata-rata yang diperoleh dari hasil jawaban responden atas pertanyaan angket Pengajaran Remedial pada skala nilai yang ditentukan oleh Purwanto(2004:32)

$i=\frac{\text { nilaitertingg } i-\text { nilaiterendah }}{\text { jarakint } \text { erval }}$

$i=\frac{4-1}{4}$

$i=0,75$

Maka berdasarkan batas interval yaitu sebesar 0,75 data diatas dapat diklarifikasikan sebagai berikut:

Tabel 5.2 : Batas Interval

\begin{tabular}{|c|c|}
\hline Interval & Kategori \\
\hline $1,00-1,74$ & Tidak baik \\
\hline $1,75-2,49$ & Kurang \\
\hline $2,50-3,24$ & Baik \\
\hline $3,25-4,00$ & Sangat baik \\
\hline
\end{tabular}

Berdasarkan tabel 5.1 distribusi frekuensi jawaban atas variabel $\mathrm{X}$ diketahui bahwa: 
1. Siswa setuju bila guru melakukan penelaahan / pengulangan kembali terhadap materi pelajaran yang telah disampaikan didalam kelas mendapat nilai rata-rata 3,42 dikategorikan sangat baik.

2. Dengan melakukan penelaahan / pengulangan siswa dapat memahami pelajaran yang telah disampaikan guru didalam kelas untuk kedua kalinya mendapat nilai rata-rata 3,35 dikategorikan sangat baik.

3. Dengan penelaahan/pengulangan yang dilakukan oleh guru dapat memberikan gambaran yang jelas terhadap kesulitan belajar yang dihadapi oleh siswa mendapat nilai rata-rata 3,33 dikategorikan sangat baik.

4. Penelaahan yang dilakukan oleh guru dapat membantu guru dalam melakukan Pengajaran Remedial terhadap siswa yang mengalami kesulitan belajar mendapat nilai rata-rata 3,46 dikategorikan sangat baik.

5. Pengajaran Remedial yang diberikan oleh guru sesuai dengan alternatif nilai yang telah ditentukan mendapat nilai rata-rata 3,42 dikategorikan sangat baik.

6. Guru pernah melakukan Pengajaran Remedial terhadap siswa yang kurang dalam belajar mendapat nilai rata-rata 3,33 dikategorikan sangat baik.

7. Guru bidang studi melakukan pelayanan berupa bimbingan dan konseling disekolah mendapat nilai rata-rata 2,89 dikategorikan baik.

8. Setelah guru memberikan pelayanan berupa bimbingan dan konseling kesulitan belajar siswa dapat teratasi mendapat nilai rata-rata 3,42 dikategorikan sangat baik.

9. Pelaksanaan Pengajaran Remedial memiliki sasaran pokok yakni meningkatkan prestasi kemampuan menyesuaikan diri dengan ketentuan yang telah ditetapkan sebelumnya oleh guru bidang studi menurut siswa sasaran ini dapat tercapai mendapat nilai rata-rata 3,04 dikategorikan baik.

10. Siswa akan mengulangi pelajaran yang telah disampaikan oleh guru disekolah setelah sampai dirumah mendapat nilai rata-rata 3,33 dikategorikan sangat baik.

11. Setelah menyampaikan pelajaran didalam kelas, guru tersebut mengulangi materi pelajaran yang belum dipahami oleh siswa mendapat nilai rata-rata 3,37 dikategorikan sangat baik.

12. Apabila guru melakukan pengukuran kembali prestasi belajar siswa didalam kelas dapat mengetahui tercapai atau tidaknya apa yang diharapkan dalam Pengajaran Remedial mendapat nilai rata-rata 2,95 dikategorikan baik.

13. Apabila guru memberikan tugas tambahan di dalam kelas siswa selalu mengerjakan dan harus dikumpulkan tepat waktu dan mendapat nilai rata-rata 3,27, dikategorikan sangat baik.

14. Setelah guru mengatahui hasil pengukuran prestasi belajar siswa guru melakukan tindak lanjut terhadap kasus tersebut. Mendapat nilai 2,85 dikategorikan baik

15. Guru melakukan pengukuran kembali prestasi belajar siswa dengan menggunakan tes seperti yang dipergunakan dalam proses belajar mengajar, mendapat nilai 3,37 dikategorikan sangat baik.

16. Siswa selalu ingin mencapai prestasi belajar yang tinggi dalam studinya, mendapat nilai 3,33 dikategorikan sangat baik.

17. Siswa yakin akan mendapatkan prestasi yang baik, mendapat nilai 2,83 dikategorikan baik.

18. Untuk mewujudkan harapan nilai yang baik siswa akan berusaha mengulang kembali pelajaran yang telah disampaikan guru di dalam kelas, mendapat nilai 3,33 dikategorikan sangat baik.

19. Siswa berjuang untuk mewujudkan potensi yang ada dalam dirinya, mendapat nilai 3,39 dikategorikan sangat baik.

20. Siswa meyakini bahwa dia pantas mendapat prestasi yang baik, mendapat nilai 3,27 dikategorikan sangat baik.

a. Pengajaran Remedial

Pengajaran Remedial adalah usaha yang dilakukan guru untuk memperbaiki nilai siswa yang mengalami kesulitan belajar. Untuk mengetahui Pengajaran Remedial (variabel $\mathrm{x}$ ) data hasil penelitian dianalisis dengan cara sebagai berikut :

Tabel 5.3 
Volume 2, Nomor 2,Oktober 2021: halaman 174-188

https://jurnal.amikwidyaloka.ac.id/index.php/awl

jurnal@amikwidyaloka.ac.id / editor.jurnalwidya@gmail.com

Distribusi Frekuensi Hasil Angket Pengajaran Remedial

\begin{tabular}{|c|c|c|c|}
\hline Kelompok & Frekuensi Absolut & Frekuensi Relatif & Kategori \\
\hline $65-$ keatas & 30 & $62,50 \%$ & Tinggi \\
\hline $50-64$ & 15 & $31,25 \%$ & Cukup \\
\hline $35-49$ & 3 & $6,25 \%$ & Kurang \\
\hline $34-$ kebawah & 0 & $0,00 \%$ & Rendah \\
\hline Total & 48 & $100 \%$ & \\
\hline
\end{tabular}

(Perhitungan selengkapnya terdapat dalam lampiran 7)

Dari data perhitungan yang diperoleh di atas berdasarkan dari hasil perhitungan :

1. Rata-rata skor dihitung dengan rumus :

$$
\begin{aligned}
& \mathrm{Mi}=\frac{\text { shor tertinggi }+ \text { shor tereniah ideal }}{2} \\
& \mathrm{Mi}=\frac{(20 \times 4)+(20 \times 1)}{2} \\
& \mathrm{Mi}=\frac{80+20}{2} \\
& \mathrm{Mi}=\frac{100}{2} \\
& \mathrm{Mi}=50,00
\end{aligned}
$$

2. Standart Deviasi

Simpangan baku dan ubahan penelitian dihitung dengan rumus

Sdi $=$

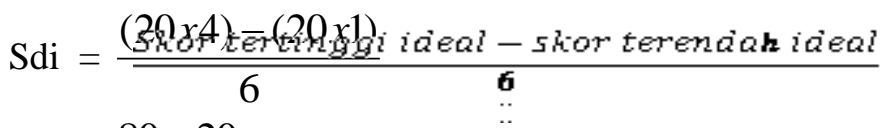

Sdi $=\frac{80-20}{6}$

$\operatorname{Sdi}=\frac{60}{6}$

Sdi $=10,00$

Dan distribusi frekuensi Pengajaran Remedial di atas dapat dilihat pada gambar histogram sebagai berikut :

Gambar 5.1 Histogram Pengajaran Remedial (variabel x) 


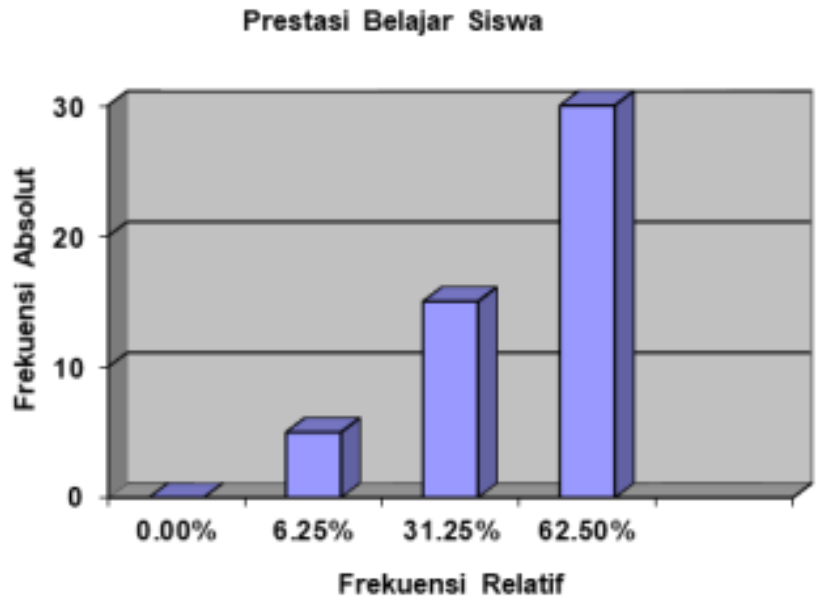

Dari tabel di atas maka dapat diketahui bahwa terdapat 3 (6,25\%) Pengajaran Remedial yang diberikan kepada siswa dengan kategori kurang, dan terdapat 15 (31,25\%) Pengajaran Remedial yang diberikan kepada siswa dengan kategori cukup, serta terdapat $30(62,50 \%)$ pengajaran yang diberikan kepada siswa dengan kategori tinggi. Dengan demikian maka dapat disimpulkan Pengajaran Remedial siswa tergolong kategori tinggi yaitu $30(62,50 \%)$.

a. Prestasi Belajar

Prestasi belajar adalah hasil yang diperoleh siswa setelah melalui usaha belajar yang dilakukan dalam kurun waktu tertentu yang dilihat dari nilai raport siswa.

Tabel 5.4

Tingkat Kecenderungan Prestasi Belajar Siswa Kelas X SMA Yayasan Perguruan Gajah Mada Medan T.P. 2019/2020

\begin{tabular}{|c|c|c|c|}
\hline Rentangan & F. Absolut & F. Relatif & Kategori \\
\hline $65-$ keatas & 41 & $85,4 \%$ & tinggi \\
\hline $50-64$ & 7 & $14,6 \%$ & cukup \\
\hline $35-49$ & 0 & $0,00 \%$ & kurang \\
\hline $34-$ kebawah & 0 & $0,00 \%$ & rendah \\
\hline Total & 48 & $100 \%$ & \\
\hline
\end{tabular}

Dari hasil penelitian diperoleh rata-rata skor prestasi belajar ekonomi siswa kelas X SMA Yayasan Perguruan Gajah Mada T.P. 2019/2020 sebesar 0,584 atau 85,4\%, ini menunjukkan bahwa prestasi belajar ekonomi siswa menunjukkan hasil yang tinggi dan dari hasil distribusi frekuensi prestasi belajar ekonomi siswa di atas dapat dilihat pada diagram batang sebagai berikut :

\section{Gambar 5.2 Histogram Prestasi Belajar Siswa (Variabel Y)}




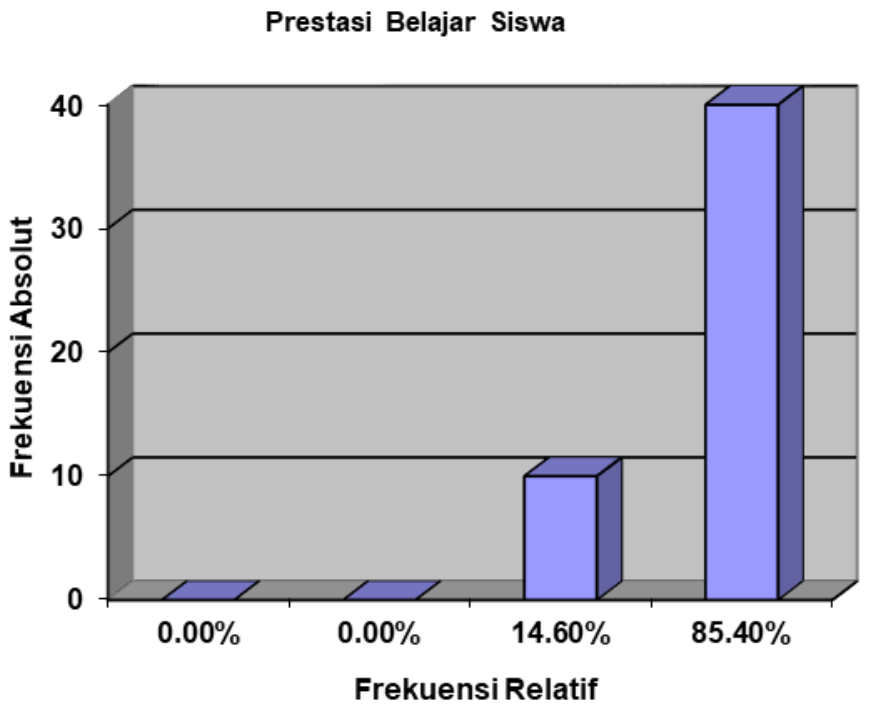

\subsubsection{Analisis Data}

a. Analisis Korelasi

Untuk menghitung koefisien korelasi antara variabel penelitian digunakan rumus Korelasi Product Moment angka kasar sebagai berikut :

dimana :

$$
\mathrm{r}_{\mathrm{xy}}=\frac{N \sum X Y-\left(\sum X\right)\left(\sum Y\right)}{\sqrt{\left(N \sum X^{2}-\left(\sum X\right)^{2}\right)\left(N \sum Y^{2}-\left(\sum Y\right)^{2}\right)}}
$$

$\mathrm{r}_{\mathrm{xy}} \quad=$ koefisien korelasi antara variabel $\mathrm{x}$ dan $\mathrm{y}$

$\mathrm{xy} \quad=$ jumlah perkalian antara nilai variabel $\mathrm{x}$ dan $\mathrm{y}$

$\mathrm{N} \quad=$ jumlah responden

$\left(\sum \mathrm{x}^{2}\right)=$ jumlah kuadrat dari nilai variabel $\mathrm{x}$

$\left(\sum \mathrm{y}^{2}\right)=$ jumlah kuadrat dari nilai variabel $\mathrm{y}$ berikut :

Berdasarkan dari data temuan hasil penelitian diperoleh data-data variabel $\mathrm{x}$ dan $\mathrm{y}$ sebagai

$$
\begin{aligned}
\mathrm{N} & =48 \\
\sum \mathrm{x} & =3224 \\
\sum \mathrm{y} & =3740 \\
\sum \mathrm{x}^{2} & =220929 \\
\sum \mathrm{y}^{2} & =295644 \\
\sum \mathrm{xy} & =254852
\end{aligned}
$$

sehingga nilai $\mathrm{r}_{\mathrm{xy}}$ adalah :

$$
\begin{aligned}
& \mathrm{r}_{\mathrm{xy}}=\frac{N \sum X Y-\left(\sum X\right)\left(\sum Y\right)}{\sqrt{\left(N \sum X^{2}-\left(\sum X\right)^{2}\right)\left(N \sum Y^{2}-\left(\sum Y\right)^{2}\right)}} \\
& \mathrm{r}_{\mathrm{xy}}=\frac{48.254852-(3224)(3740)}{\sqrt{\left(48.220929-(3224)^{2}\right)\left(48.295644-(3740)^{2}\right)}} \\
& \mathrm{r}_{\mathrm{xy}}=\frac{12232896-12057760}{\sqrt{(10604592-10394176)(14190912-13987600)}}
\end{aligned}
$$




$$
\begin{aligned}
& r_{x y}=\frac{175136}{\sqrt{(210416)(203312)}} \\
& r_{x y}=\frac{175136}{\sqrt{4278009710}} \\
& r_{x y}=\frac{175136}{\sqrt{206833,5}} \\
& r_{x y}=0,85
\end{aligned}
$$

Dari tabel kritik $\mathrm{r}$ pada taraf signifikasi $95 \%$ dengan jumlah responden 48 orang siswa sehingga diperoleh harga $r_{\text {tabel }}$ sebesar $=0,285$. Dan dari perhitungan dengan menggunakan rumus korelasi product moment diatas diperoleh harga $r_{\text {hitung }}$ sebesar $=0,85$. Dengan demikian harga $r_{\text {hitung }}>$ $\mathrm{t}_{\text {tabel }}$ yaitu 0,85>0,285, sehingga koefisien korelasi $\mathrm{x}$ dan y diketahui signifikan.

Untuk mengetahui tingkat korelasi (hubungan antara Pengajaran Remedial dengan prestasi belajar ekonomi siswa dapat dianalisa menurut analisa korelasi Sugiono (2003:216) yang menyatakan
$0,00-0,19 \quad$ korelasi sangat rendah
$0,21-0,39 \quad$ korelasi rendah
$0,40-0,59 \quad$ korelasi sedang
$0,60-0,79 \quad$ korelasi kuat
$0,80-0,99 \quad$ korelasi sangat kuat

Dari hasil perhitungan koefisien korelasi dengan menggunakan rumus product moment antara Pengajaran Remedial (variabel $\mathrm{x}$ ) dengan prestasi belajar siswa kelas X (variabel y) diperoleh harga koefisien sebesar 0,85 dengan tingkat hubungan sangat kuat, selanjutnya harga korelasi ini dikonsultasikan dengan $r_{\text {tabel }}$ pada taraf signifikan 95\% atau alpha $\alpha=0,05$ diperoleh harga $r_{\text {tabel }} 0,285$, maka dapat dikatakan bahwa $r_{\text {hitung }}>r_{\text {tabel }}(0,85>0,285)$. Artinya semakin efektif Pengajaran Remedial diberikan kepada siswa maka prestasi belajarnya pun akan semakin tinggi atau dengan kata lain dapat dikatakan bahwa jika terjadi peningkatan nilai pada pengajaran remedial maka prestasi belajarnya juga akan semakin meningkat sering perubahan yang terjadi pada nilai (x). Sebaliknya penurunan nilai pada Pengajaran Remedial akan mempengaruhi prestasi belajar siswa.

b. Pengujian Hipotesis

Untuk menguji hipotesis penelitian digunakan rumus sebagai berikut :

$$
\begin{aligned}
\mathrm{t} & =\sqrt[r]{\frac{N-2}{1-r^{2}}} \\
& =\sqrt[0,85]{\frac{48-2}{1-0,85^{2}}} \\
& =\sqrt[0,85]{\frac{46}{1-0,7225}} \\
& =\sqrt[0,85]{\frac{46}{0,2775}} \\
& =\quad \sqrt[0,85]{165,76} \\
& =\quad \mathbf{0 , 8 5} \times \mathbf{1 2 , 9} \\
& =\quad \mathbf{1 0 , 9 6 5}
\end{aligned}
$$

Karena harga $r_{\text {tabel }}$ pada taraf signifikan 95\% atau alpha $\alpha=0,05$ dengan $\mathrm{dk}=\mathrm{n}-2=48-2=$ 46 tidak terdapat dalam daftar distribusi " $t$ " maka untuk mencari harga $r_{\text {tabel }}$ dapat dilakukan dengan cara interpolasi sebagai berikut : $\mathrm{t}(0,05)(46)=(\mathrm{x})$ ? 
$\mathrm{t}(0,05)(40)=1,684$

$\mathrm{t}(0,05)(60)=1,671$

maka $t_{\text {tabel }}$ adalah :

$$
\begin{aligned}
\mathrm{t}_{\text {tabel }} & =1,684+\frac{46-40}{60-40}(1,671-1,684) \\
& =1,684+\frac{6}{20}(-0,013) \\
& =1,684+0,3(-0,013) \\
& =1,684-0,0039 \\
& =1,6801
\end{aligned}
$$

Dari perhitungan diatas diperoleh $\mathrm{t}_{\text {hitung }} 1,6801$ sedangkan $\mathrm{t}_{\text {hitung }}$ sebesar 10,965 , yang berarti bahwa $r_{\text {hitung }}>r_{\text {tabel }}$ yaitu 10,965 >1,6801. Dengan demikian maka hipotesis yang menyatakan bahwa terdapat hubungan yang positif dan signifikan antara Pengajaran Remedial dengan prestasi belajar ekonomi siswa kelas X SMA Yayasan Perguruan Gajah Mada T.P. 2019/2020 dapat diterima.

(Tulis di sini) ... Bagian ini menyajikan hasil penelitian, jumlah halaman 25-30\% dari total halaman. Hasil penelitian dapat dilengkapi dengan tabel, grafik (gambar), dan/ atau bagan. Bagian pembahasan memaparkan hasil pengolahan data, menginterpretasikan penemuan secara logis, mengaitkan dengan penelitian lain atau sumber rujukan yang relevan. Sebutkan kelebihan dan keunikan penelitian ini dibandingkan dengan penelitian lain [Times New Roman, 11, normal], spasi 1. Format gambar png/ jpg. Struktur penulisan hasil harus matching dengan metode penelitian, sehingga setiap langkah dalam metode diberikan hasil dan pembahasannya.

Pengajaran Remedial adalah upaya guru untuk menciptakan suatu kondisi yang memungkinkan individu atau kelompok siswa lebih mampu mengembangkan dirinya seoptimal mungkin sehingga dapat meningkatkan motivasi belajar siswa dan mampu memenuhi kriteria keberhasilan minimal yang diharapkan. Dari hasil penelitian diperoleh distribusi frekuensi jawaban angket Pengajaran Remedial (variabel x) oleh siswa kelas X SMA Yayasan Perguruan Gajah Mada dengan nilai rata-rata sebesar 3,25 dikategorikan sangat baik.

Hasil dari nilai rata-rata prestasi belajar ekonomi siswa sebesar 77,92. Hal ini menunjukkan bahwa nilai belajar siswa kelas X SMA Yayasan Perguruan Gajah Mada Medan T.P. 2019/2020 termasuk kategori baik.

Tingkat kecenderungan Pengajaran Remedial berada pada 30 (62,50)\% dikategorikan tinggi, $15(31,25) \%$ dikategorikan cukup, 3(6,25)\% dikategorikan kurang. Sementara itu tingkat kecenderungan prestasi belajar siswa kelas X SMA Yayasan Perguruan Gajah Mada T.P. 2019/2020 berada pada $4(85,4) \%$ dikategorikan tinggi dan $17(14,6) \%$ dikategorikan cukup. Walaupun demikian masih diperoleh beberapa siswa yang tidak memiliki prestasi belajar yang rendah oleh karena itu guru perlu melakukan tugas tambahan kepada siswa guna mendiagnosa kesulitan-kesulitan belajar yang dihadapi siswa dalam kegiatan belajar.

Berdasarkan uji korelasi terdapat hubungan antara Pengajaran Remedial (x) dengan prestasi belajar siswa kelas X SMA Yayasan Perguruan Gajah Mada T.P. 2019/2020 diperoleh koefisien korelasi sebesar 0,85 dengan tingkat hubungan tinggi, sedangkan dari daftar $\mathrm{r}$ diperoleh harga $\mathrm{r}_{\text {tabel }}$ sebesar 0,285 pada taraf signifikansi 95\% atau alpha $\alpha=0,05$ sehingga dapat dikatakan $r_{\text {hitung }}>r_{\text {tabel }}$ $(0,85>0,285)$. Artinya semakin tinggi Pengajaran Remedial yang diberikan maka prestasi belajar siswa akan semakin tinggi.

Pengujian hipotesis dilakukan dengan menggunakan uji " $\mathrm{t}$ ", dmana dari hasil perhitungan, diperoleh $t_{\text {hitung }}$ sebesar 10,965. sedangkan $t_{\text {tabel }}$ diperoleh dengan taraf signifikansi $95 \%$ atau alpha $\alpha=0,05$, sehingga dengan demikian maka hipotesis yang mengatakan bahwa terdapat hubungan antara Pengajaran Remedial dengan prestasi belajar siswa kelas X SMA Yayasan Perguruan Gajah Mada Medan T.P. 2019/2020 dapat diterima. 
Dari hasil penelitian tentang "Hubungan Pengajaran Remedial dengan Prestasi Belajar Ekonomi siswa kelas X SMA Yayasan Perguruan Gajah Mada Medan Tahun Pembelajaran 2019/2020" dengan penelitian yang relevan dari hasil penelitian tersebut, hasil yang ditunjukkan adalah bahwa ada hubungan yang positif dan signifikan antara pengajaran remedial dengan prestasi belajar ekonomi siswa kelas X SMA Yayasan Perguruan Gajah Mada Medan.

\section{$5 \quad$ Kesimpulan (Conclusion)}

1. Dari distribusi frekwensi jawaban angket Pengajaran Remedial prestasi belajar siswa bidang studi ekonomi dengan nilai rata-rata 3,25 termasuk kategori sangat baik.

2. Dari hasil penelitian yang diperoleh rata-rata prestasi belajar ekonomi siswa sebesar 77,92. Ini menunjukkan bahwa nilai prestasi belajar siswa kelas X SMA Yayasan Perguruan Gajah Mada Medan T.P. 2019/2020 dikategorikan baik.

3. Uji korelasi product moment diperoleh $\mathrm{r}_{\text {hitung }}$ sebesar 0,85 artinya adalah terdapat hubungan antara Pengajaran Remedial dengan prestasi belajar ekonomi siswa ada pada taraf hubungan yang kuat.

Dari perhitungan dengan menggunakan uji " $\mathrm{t}$ " yang digunakan untuk melihat kebenaran hipotesis diperoleh nilai $t_{\text {hitung }}$ sebesar 10,965 sedangkan $t_{\text {tabel }}$ sebesar 1,6801. Dengan demikian $t_{\text {hitung }}>t_{\text {tabel }}$ $(10,965>1,6801)$ pada taraf signifikannya $95 \%$ atau alpha 0,05 . Dengan demikian hipotesis yang mengatakan bahwa :"terdapat hubungan yang positif dan signifikan antara Pengajaran Remedial dengan prestasi belajar siswa kelas X SMA Yayasan Perguruan Gajah Mada medan T.P. 2019/2020 dapat diterima".

1. Adapun saran dari peneliti sebagai berikut :

Mengingat pentingnya Pengajaran Remedial dalam menumbuhkan kualitas belajar siswa,

disarankan kepada semua guru terutama yang belum terbiasa melaksanakan remedial agar senantiasa meningkatkan kemampuan dan kualitas dalam melaksanakan Pengajaran Remedial.

2. Walaupun prestasi siswa di SMA Yayasan Perguruan Gajah Mada T.P. 2019/2020 tergolong baik tapi sebaiknya pihak sekolah dapat melakukan hal-hal yang biasa meningkatkan prestasi belajar siswa, misalnya memberikan perhatian terhadap siswa yang memiliki karakter yang berada satu sama lian. Selain itu juga dapat dilakukan bimbingan dan konseling sebagai pendekatan bagi siswa terutama yang mengalami kesulitan dalam belajar.

Bagi guru (tenaga pendidik) hendaknya menyadari bahwa Pengajaran Remedial merupakan salah satu faktor penting dalam mengatasi kesulitan belajar sehingga prestasi belajar siswa dapat tercapai dengan optimal.

\section{Referensi (Reference)}

[1] Arikunto, Suharsimi. 2002. Prosedur Penelitian. Jakarta : Rineka Cipta

[2] Hakim, Thursan. 2004. Belajar Secara Efektif. Jakarta : Puspa Swara

[3] Hamalik, Oemar. 2001. Proses Belajar Mengajar. Jakarta : Uni Aksara

[4] Makmun, S, Abin. 2004. Cara Belajar. Jakarta : BPK Gunung Mulia

[5] Rusmini, Mukhtar. 2005. Pengajaran Remedial. Jakarta : Nimas Multima

[6] Slameto. 2001. Belajar dan Faktor-faktor yang Mempengaruhinya. Jakarta : Bina Aksara

[7] Sofa. 2008. Memahami Kegiatan Remedial Untuk Perbaikan Pembelajaran. http:// massofa.wordpress.com. Diakses 15 September 2009

[8] Sudjana. 2002. Metode Statistika. Bandung : Tarsito

[9] Syah, Muhibin. 2003. Psikologi Belajar. Jakarta : Raja Grafindo Persada 